\title{
Pelaksanaan Upaya Hukum Banding Oleh Notaris Atas Putusan Majelis Pengawas Wilayah Provinsi Bali
}

\author{
Gusti Ayu Indira Chandra Mahayani' ${ }^{1}$ I Wayan Parsa ${ }^{2}$, \\ I Nyoman Sumardika ${ }^{3}$
}

\begin{abstract}
1Fakultas Hukum Universitas Udayana,E-mail: gaindirachandra@gmail.com
${ }^{2}$ Fakultas Hukum Universitas Udayana

${ }^{3}$ Fakultas Hukum Universitas Udayana
\end{abstract}

\begin{tabular}{l} 
Info Artikel \\
\hline Keywords : \\
Notar; Supervision, Decision's \\
Letter; Appeal; Regional \\
Supervisory Council \\
\\
Corresponding Author: \\
Gusti Ayu Indira Chandra \\
Mahayani, E-mail: \\
gaindirachandra@gmail.com \\
Notaris, Pengawasan, Putusan, \\
Wanding, Majelis Pengawas \\
Wilayah \\
\end{tabular}

\begin{abstract}
The Article 73 (1) (e) of the Law 2/2014 concerning the Amendment of Law 30/2004 on Public Notary (UUJNP), regulates that the Regional Supervisory Council (MPW) has the authority to give sanction to a public notary, either verbally or in written. However, based on the empirical findings, there is a decision of Bali's MPW that gives temporary suspension to Notary X. This finding, reflects the gap between the theory of law and its actual implementation of a supervisory conduct of the Bali's MPW, specifically on giving a punishment. The purpose of this study is to critically analyze the legal position of the decision of the Supervisory Board of the Bali Province Region as a decision of the State Administration Officer and Identify the implementation of an appeal by the Notary X on the decision of the Bali Province Regional Supervisory Board. By using the juridic empirical approach, which the primary sources were obtained through indepth interviews with interviewees and the secondary sources of data were obtained through library research on primary, secondary, and tertiary source of law. This research shows that the appeal process was effectively conducted as required by the Article 77 UUJNP and Article 33 vide Article 35 Miniter of Law and Human Rights Regulation M.02.Pr.08.10/2004 and the decision's letter of Bali's MPW as a state officials could be subjected to a lawsuit by a public notary or any other affected parties to the State Administration Court as an Administrative Dispute. However, until 2018 there are no decisions of Bali Province's MPW ever being sued to the Administrative Court.
\end{abstract}


DOI :

10.24843/AC.2018.v03.i02.p02 kesenjangan antara teori dan praktik pengawasan oleh MPW Provinsi Bali dalam memberikan sanksi. Tujuan penelitian ini untuk menganalisis secara kritis kedudukan hukum keputusan Majelis Pengawas Wilayah Provinsi Bali sebagai keputusan Pejabat Tata Usaha Negara serta mengidentifikasi pelaksanaan upaya hukum banding oleh Notaris X atas putusan Majelis Pengawas Wilayah Provinsi Bali dengan menggunakan metode penelitian yuridis empiris yang data primernya didapatkan melalui wawancara secara langsung kepada para responden di lapangan, dan data sekundernya diperoleh dengan melakukan penelitian kepustakaan terhadap bahan hukum primer, sekunder, dan tersier sesuai dengan permasalahan yang ditentukan. Hasil penelitian ini menunjukan bahwa pelaksanaan upaya hukum banding oleh Majelis Pengawas Pusat telah dilaksanakan dengan efektif sesuai dengan Pasal 77 UUJNP dan Pasal 33 jo. Pasal 35 Permenkumham Nomor: M.02.Pr.08.10 Tahun 2004 dan surat keputusan MPW Provinsi Bali sebagai Pejabat Tata Usaha Negara dapat dijadikan objek gugatan oleh Notaris maupun pihak lain yang merasa kepentingannya dirugikan ke Pengadilan Tata Usaha Negara sebagai sengketa Tata Usaha Negara. Akan tetapi, hingga tahun 2018 belum pernah ada keputusan Majelis Pengawas Wilayah Provinsi Bali yang digugat hingga ke Peradilan Tata Usaha Negara.

\section{Pendahuluan}

Pejabat umum adalah jabatan yang diciptakan Negara sebagai implementasi dari Negara dalam memberikan pelayanan kepada rakyat yang diangkat serta dapat diberhentikan oleh pemerintah dan juga memiliki kewenangan untuk melayani publik dalam hal-hal tertentu yang diatur oleh undang-undang tersendiri mengenai jabatan itu. ${ }^{1}$ Notaris adalah pejabat umum yang memiliki kewenangan untuk membuat akta otentik mengenai perbuatan hukum tertentu di bidang hukum perdata. Akta yang dikeluarkan Notaris merupakan bukti kuat dalam suatu proses perkara karena akta yang dibuat itu merupakan dokumen negara, dan seorang Notaris juga harus bertakwa kepada Tuhan yang maha esa, sehat jasmani dan rohani, dan tentunya juga berstatus Warga Negara Indonesia (WNI). ${ }^{2}$

Notaris sebagai pejabat umum yang berwenang membuat akta otentik harus dapat mempertanggungjawabkan akta yang dibuatnya apabila ternyata dikemudian hari timbul masalah dari akta otentik tersebut. Oleh karena itu, sebagai konsekuensi logis seiring dengan besarnya peran Notaris dalam mengemban tugas dan kewenangan Notaris yang dilangsungkan secara terus menerus, begitu pula dengan penerapan sanksi, agar Notaris dalam mengembankan tugas dan kewenangannya harus sesuai dengan koridor hukum sehingga dapat terhindar dari penyalahgunaan kekuasaan

\footnotetext{
${ }^{1}$ R. Soesanto, 2007, Tugas, Kewajiban dan Hak-Hak Notaris, Wakil Notaris, Pradnya Paramita,
} Jakarta, hal. 75.

2 A. Kohar, 2005, Notaris Dalam Praktek Hukum, Alumni, Bandung, hal. 64. 
yang diberikan oleh Negara yang dapat menimbulkan ketidakpercayaan dari masyarakat, maka nilai-nilai etika dan hukum harus diterapkan dan dijunjung tinggi oleh Notaris dalam menjalankan jabatannya sesuai dengan undang-undang, bahkan notaris meskipun sebagai pejabat negara namun dalam melaksanakan profesinya juga harus diawasi secara ketat. ${ }^{3}$

Saat ini, mekanisme pengawasan yang dilakukan secara terus menerus terhadap Notaris sebagai pejabat umum yang harus selalu melaksanakan wewenang dan tugas jabatannya sesuai dengan kaidah hukum tersebut dilaksanakan berdasarkan UndangUndang Nomor 2 Tahun 2014 tentang Perubahan atas Undang-Undang Nomor 30 Tahun 2004 tentang Jabatan Notaris, (yang selanjutnya disebut UUJN Perubahan) dan Peraturan Menteri Hukum dan HAM Republik Indonesia Nomor M.02.PR.08.10 Tahun 2004 Tentang Tata Cara Pengangkatan Anggota, Pemberhentian Anggota, Susunan Organisasi, Tata Kerja, dan Tata Cara Pemeriksaan Majelis Pengawas Notaris (selanjutnya disingkat dengan PERMENKUMHAM Nomor M.02.PR.08.10 Tahun 2004). Pengawasan terhadap Notaris tersebut berada dibawah kewenangan Menteri Hukum dan Hak Asasi Manusia Republik Indonesia.

Dalam melaksanakan pembinaan dan pengawasan oleh Notaris, maka Menteri Hukum dan Hak Asasi Manusia Republik Indonesia membentuk Majelis Pengawas Notaris. Badan ini terdiri dari Majelis Pengawas Daerah, Majelis Pengawas Wilayah Provinsi dan Majelis Pengawas di wilayah Ibukota Negara. Majelis pengawas itu sendiri merupakan badan yang mempunyai kewenangan untuk melakukan pembinaan serta pengawasan terhadap Notaris mengenai perilaku dan pelaksanaan dalam menjalankan jabatannya. Selain juga melakukan pengawasan serta pemeriksaan kepada Notaris, Majelis Pengawas Notaris memilki kewenangan untuk dapat memberikan sanksi tertentu terhadap Notaris yang terbukti bersalah dalam mengemban dan menjalankan tugas jabatan Notaris sehingga Notaris dapat dihukum. Namun kewenangan untuk menjatuhkan sanksi hanyalah kewenangan Majelis Pengawas Wilayah dan Majelis Pengawas Pusat.

Kewenangan Majelis Pengawas Wilayah dalam mengawasi Notaris diatur dalam Pasal 73 ayat (1) UUJN Perubahan yang mengatur bahwa Majelis Pengawas Wilayah berwenang:

a. memeriksa serta mengambil keputusan atas laporan masyarakat dengan menyelenggarakan sidang atas putusan yang disampaikan melalui Majelis Pengawas Daerah;

b. melakukan pemanggilan kepada Notaris untuk dapat dilaksanakan pemeriksaan atas laporan kepadanya;

c. memberikan izin cuti dari enam (6) bulan hingga satu (1) tahun;

d. memeriksa dan memutus atas keputusan Majelis Pengawas Daerah yang menolak cuti yang diajukan oleh Notaris pelapor;

e. memberikan sanksi secara lisan ataupun tertulis;

f. mengusulkan diberikannya sanksi terhadap Notaris kepada Majelis Pengawas Pusat Notaris yang berupa:

\footnotetext{
3 Putra, D. N. R. A., \& Purwani, S. P. M. (2016). Pengawasan Notaris Oleh Majelis Pengawas Notaris Daerah Pasca Putusan MK No. 49/Puu-X/2012. Jurnal Magister Hukum Udayana (Udayana Master Law Journal), 5(4), 786.
} 
1) adanya pemberhentian sementara;

2) pemberhentian secara tidak hormat

Terkait dengan kewenangan MPW dalam memberikan sanksi, MPW hanya berwenang memberikan sanksi berupa peringatan lisan maupun peringatan tertulis. Akan tetapi berdasarkan fakta di lapangan, terdapat Putusan MPW Provinsi Bali atas kasus Notaris $X$ yang amar putusannya tidak sesuai dengan ketentuan Pasal 73 ayat (1) huruf e UUJNP. Terhadap penyelesaian kasus yang terjadi antara Notaris $X$ dengan kliennya, MPW Provinsi Bali seharusnya memberikan putusan berupa peringatan lisan atau peringatan tertulis, akan tetapi MPW Provinsi Bali telah melampaui kewenangannya dengan memberikan sanksi berupa pemberhentian sementara kepada Notaris X. Hal ini dapat dilihat dalam amar putusan MPW Provinsi Bali atas Notaris $X$ yang menyatakan:

"Menghukum oleh karenanya Saudara X, Notaris Kabupaten Badung dengan sanksi PEMBERHENTIAN SEMENTARA 3 bulan sampai 6 bulan karena telah melanggar Pasal 15 ayat (2) huruf e dan Pasal 16 ayat (1) huruf a UU Nomor 30 Tahun 2004 tentang Jabatan Notaris dan melanggar Pasal 3 angka $(2,4)$ dan Pasal 4 angka (8) Kode Etik Notaris sebagaimana dimaksud Pasal 73 ayat (1) huruf f UUJN dan Pasal 31 ayat (2) huruf c Peraturan Menteri Hukum dan Hak Asasi Manusia Republik Indonesia Nomor: M.02.PR.08.10 Tahun 2004 tentang Tata Cara Pengangkatan Anggota, Pemberhentian Anggota, Susunan Organisasi, Tata Kerja dan Tata Cara Pemeriksaan Majelis Pengawas Notaris."

Hal ini menggambarkan adanya kesenjangan antara teori dan praktik pengawasan oleh MPW Provinsi Bali dalam memberikan sanksi. Suatu kepastian hukum tidak hanya menjadi tanggung jawab Notaris dalam melaksanakan kewajibannya sebagai pejabat umum, akan tetapi Majelis Pengawas Notaris yang memiliki tugas pokok serta fungsi untuk melakukan pemeriksaan dan pemberian sanksi terhadap perkara-perkara yang melibatkan Notaris pun sudah seharusnya dapat memberikan suatu kepastian hukum bagi para pihak yang berperkara. Jika penyelesaian suatu kasus tidak mengindahkan kewenangan sesuai dengan peraturan yang berlaku, maka sudah pasti tidak akan tercapai suatu kepastian hukum.

Berdasarkan latar belakang di atas, Penulis tertarik melakukan penelitian dengan judul "Pelaksanaan Upaya Hukum Banding Oleh Notaris Atas Putusan Majelis Pengawas Wilayah Provinsi Bali" sehingga dapat dikemukakan rumusan masalah sebagai berikut:

1. Bagaimana kedudukan hukum keputusan Majelis Pengawas Wilayah Provinsi Bali sebagai keputusan Pejabat Tata Usaha Negara?

2. Bagaimana pelaksanaan upaya hukum banding oleh Notaris $X$ atas putusan Majelis Pengawas Wilayah Provinsi Bali?

Tujuan studi ini, yakni untuk menganalisis secara kritis kedudukan hukum keputusan Majelis Pengawas Wilayah Provinsi Bali sebagai keputusan Pejabat Tata Usaha Negara serta Mengidentifikasi pelaksanaan upaya hukum banding oleh Notaris $\mathrm{X}$ atas putusan Majelis Pengawas Wilayah Provinsi Bali.

Jenis penelitian yang digunakan di dalam menjawab permasalahan ini adalah penelitian hukum empiris, yang mana di dalam penelitian ini terdapat kesenjangan antara das sollen dan das sein yaitu kesenjangan antara teori dan kenyataan atau 
kesenjangan teoritis dengan fakta hukum, yaitu adanya kesenjangan antara Pasal 73 ayat (1) huruf e Undang-Undang Nomor 2 Tahun 2014 tentang Perubahan Atas Undang-Undang Nomor 30 Tahun 2004 tentang Jabatan Notaris dengan fakta-fakta yang terjadi di lapangan.

\section{Metode Penelitian}

Jenis penelitian di dalam penulisan hukum ini merupakan jenis penelitian hukum empiris, yang dalam mengumpulkan datanya menggunakan dua teknik, yaitu teknik studi dokumen dan teknik wawancara (interview). Apabila keseluruhan data yang diperoleh telah terkumpul baik melalui studi kepustakaan ataupun dengan wawancara, kemudian data-data tersebut akan diolah dan dianalisis secara kualitatif yaitu dengan menghubungkan data-data yang ada untuk selanjutnya disajikan secara deskriptif kualitatif dan sistematis.

\section{Hasil dan Pembahasan}

3.1 Kedudukan Hukum Keputusan Majelis Pengawas Wilayah Provinsi Bali sebagai Keputusan Pejabat Tata Usaha Negara

Kedudukan Menteri Hukum dan Hak Asasi Manusia dalam menjalankan serta melaksanakan urusan pemerintah yang berdasarkan kepada peraturan perundangundangan membawa konsekuensi terhadap Majelis Pengawas Wilayah Provinsi Bali, yaitu Majelis Pengawas Wilayah Provinsi Bali yang memiliki kedudukan sebagai Badan atau jabatan Tata Usaha Negara (TUN) yang diberikan delegasi oleh Menteri selaku Badan atau Jabatan yang berkedudukan sebagai Badan atau Jabatan TUN.

Maka dari itu, Majelis Pengawas Wilayah Provinsi Bali merupakan:4

1. Pejabat Tata Usaha Negara (TUN);

2. Dapat menjalankan urusan pemerintahan;

3. Dapat melakukan pengawasan kepada Notaris sesuai dengan UUJN berdasarkan perundang-undangan yang berlaku.

Pada pelaksanaan pengawasan, pemeriksaan serta juga dalam pemberian sanksi, Majelis Pengawas Wilayah Provinsi Bali harus didasarkan kepada kewenangan yang ditentukan oleh UUJN sebagai acuan ataupun pedoman dalam mengambil putusan. Hal ini perlu diperhatikan serta dimengerti karena anggota Majelis Pengawas Wilayah Provinsi Bali tidak seluruhnya berasal dari Notaris, sehingga segala tindakan yang berupa keputusan yang dibuat oleh Majelis Pengawas Wilayah Provinsi Bali harus mencerminkan tindakan suatu Majelis Pengawas Notaris sebagai suatu badan hukum, bukan hanya sebagai tindakan seorang atau 2 (dua) orang anggota.

\footnotetext{
${ }^{4}$ Habib Adjie, 2011, Majelis Pengawas Notaris sebagai Pejabat Tata Usaha Negara, Refika Aditama, Bandung, hal. 42.
} 
Majelis Pengawas Wilayah Provinsi Bali dalam kedudukannya sebagai satu-satunya institusi yang berwenang melakukan pengawasan serta memiliki kewenangan untuk membuat atau mengeluarkan Surat Keputusan dari hasil yang telah dilakukan dalam proses pengawasan, pemeriksaan ataupun memberikan sanksi kepada notaris yang terbukti melanggar atau menyeleweng dari peraturan jabatan notaris tersebut, dengan melihat dari ketentuan Pasal 1 angka 3 Undang-Undang Nomor 5 Tahun 1986 tentang Peradilan Tata Usaha Negara yang mengatur bahwa keputusan yang dikeluarkan dari instansi yang berwenang atau pejabat Tata Usaha Negara yang berupa penetapan secara tertulis yang berisi perbuatan hukum Tata Usaha Negara berdasarkan peraturan perundang-undangan yang berlaku, yang bersifat konkrit, individual dan final, yang dapat menimbulkan sebuah akibat hukum bagi individu ataupun oleh badan hukum perdata.

Dalam kedudukannya tersebut, Majelis Pengawas Wilayah Provinsi Bali dalam keputusannya yang ditetapkan dalam bentuk surat, dapat dijadikan sebagai objek gugatan oleh Notaris kepada Pengadilan Tata Usaha Negara (PTUN) sebagai sebuah sengketa Tata Usaha Negara. Pada Pasal 1 ayat (4) Undang-Undang Nomor 5 Tahun 1986, ditentukan mengenai definisi Sengketa Tata Usaha Negara yakni:

“Sengketa Tata Usaha Negara adalah sengketa yang timbul dalam bidang Tata Usaha Negara antara orang atau badan hukum perdata atau Pejabat Tata Usaha Negara, baik di pusat maupun di daerah, sebagai akibat dikeluarkannya Keputusan Tata Usaha Negara, termasuk sengketa kepegawaian berdasarkan peraturan perundang-undangan yang berlaku."

Apabila Notaris tersebut ada merasa bahwa sebuah keputusan yang dibuat oleh Majelis Pengawas Wilayah Provinsi Bali itu tidak transparan atau tidak berimbang dikarenakan keputusan yang dibuat tidak tepat dengan memberatkan kepada Notaris yang bersangkutan itu sehingga sangat merugikan Notaris dalam hal pemeriksaan yang membuat Notaris itu terpojok maka Notaris memiliki kesempatan untuk bisa melakukan pengajuan kepada PTUN, pengajuan itu akan terbuka setelah adanya upaya pemenuhan upaya administrasi baik keberatan administratif maupun pada banding administrasi juga telah ditempuh semuanya, walaupun pada aturan hukum yang bersangkutan telah menentukan bahwa putusan yang dibuat oleh badan atau Jabatan TUN telah final atau tidak dapat ditempuh dengan berbagai upaya hukum lain karena pada dasarnya, penggunaan upaya administrasi dalam sengketa Tata Usaha Negara didasarkan terhadap sebuah sikap yang tidak puas kepada perbuatan atau keputusan yang dilakukan oleh Tata Usaha Negara. ${ }^{5}$

Hal ini selaras dengan hukum acara sebagaimana diatur dalam Pasal 53 ayat (1) Undang-Undang Nomor 5 Tahun 1986 yang menentukan bahwa seseorang atau badan hukum perdata yang kepentingannya dirugikan oleh suatu keputusan Tata Usaha Negara dapat mengajukan gugatan tertulis kepada Pengadilan Tata Usaha Negara. Adapun dasar alasan gugatan tersebut diatur lebih lanjut dalam Pasal 53 ayat (2), yang isinya menyatakan bahwa alasan gugatan yang dapat digunakan terdiri atas:

${ }^{5}$ Habib Adjie, Op.Cit., hal. 48. 
a. Putusan yang ditetapkan oleh Tata Usaha Negara itu bertentangan pada Undang-Undang yang berlaku sehingga dapat digugat;

b. Putusan yang dikeluarkan oleh Badan atau Pejabat Tata Usaha Negara pada waktu mengeluarkan keputusan tersebut digunakan untuk tujuan lain sebagaimana dimaksud dalam pada ayat satu (1).

c. Putusan sebagaimana dimaksud dalam ayat satu (1) setelah dilakukan pertimbangan oleh Badan atau pejabat Tata Usaha Negara (TUN) atas semua kepentingan yang tersangkut dengan putusan itu yang seharusnya tidak sampai pada tindakan pada pengambilan atau ketidak adanya putusan tersebut.

Maka dengan ini, sesuai dengan ajaran hukum dan dengan demikian juga yang ditentukan dalam Pasal 53 ayat (2) Undang-Undang Nomor 5 Tahun 1986 tersebut, merupakan dasar bagi seseorang atau badan hukum perdata untuk menggugat dan sekaligus meminta pengujian oleh hakim pengadilan terhadap putusan Majelis Pengawas Wilayah Provinsi Bali sebagai Keputusan Tata Usaha Negara (KTUN). Pasal tersebut juga dapat menjadi sebuah dasar pada putusan pengadilan yang menyatakan putusan itu tidak sah atau batalnya putusan Tata Usaha Negara. ${ }^{6}$

Dalam kasus yang berkaitan dengan keputusan MPW Provinsi Bali terhadap Notaris X yang bertentangan dengan Pasal 73 ayat (1) huruf e UUJN, oleh karena Notaris X telah puas dengan hasil putusan MPP yang membatalkan putusan MPW Provinsi Bali dan membebaskan Notaris $X$ dari segala tuntutan, maka tidak terdapat upaya hukum lebih lanjut ke PTUN yang dilakukan Notaris X. Akan tetapi apabila terdapat pihak lain baik orang perseorangan maupun badan hukum perdata yang merasa kepentingannya dirugikan dengan adanya putusan dari MPP yang membatalkan putusan MPW Provinsi Bali atas Notaris X, maka pihak-pihak tersebut masih dimungkinkan untuk menggugat putusan MPP ke PTUN. Akan tetapi, berdasarkan hasil wawancara dengan I Ketut Sadi selaku Sekretaris MPW Provinsi Bali, belum pernah ada keputusan MPW Provinsi Bali yang diajukan hingga ke Peradilan Tata Usaha Negara.

\subsection{Pelaksanaan Upaya Hukum Banding Oleh Notaris X Atas Putusan Majelis Pengawas Wilayah Provinsi Bali}

Diharapkan Notaris dalam mengembankan tugas dan jabatannya harus berdasarkan pada ketentuan Pasal 16 dan juga tidak dengan melakukan perbuatan hukum yang dilarang sebagaimana dalam Pasal 17 UUJNP, maka pengawasan akan dilakukan oleh Menteri terhadap kinerja Notaris. Dalam melakukan pengawasan kepada kinerja Notaris dalam mengemban tugas serta jabatannya, Menteri membentuk Majelis Pengawas Notaris. Majelis Pengawas Notaris tersebut akan melakukan pengawasan terhadap perilaku atau perbuatan Notaris selama menjalankan jabatannya.

Pasal 1 angka 6 UUJNP, yang dimaksud Majelis Pengawas Notaris adalah merupakan suatu badan yang kewenangannya serta kewajibannya melakukan pengawasan secara berkala dan juga pembinaan terhadap Notaris sehingga Notaris itu tidak akan menyeleweng dari jabatannya sesuai dengan standar kode etik Notaris. Hal ini senada dengan definisi Majelis Pengawas Notaris yang diatur dalam Pasal 1 angka 2

${ }_{6}$ Philipus M Hadjon dan Tatiek Sri Djatmiati, 2008, Argumentasi Hukum, Gajah Mada University Press, Yogyakarta, hal. 83. 
Peraturan Menteri Hukum dan Hak Asasi Manusia Republik Indonesia Nomor 40 Tahun 2015 Tentang Susunan Organisasi, Tata Cara Pengangkatan Anggota, Pemberhentian Anggota dan Tata Kerja Majelis Pengawas mendefinisikan Majelis Pengawas Notaris yang selanjutnya disebut Majelis Pengawas sebagai suatu badan yang segala tindakan mengharuskan melakukan pembinaan dan pengawasan kepada Notaris sesuai dengan visi misi dari Majelis Pengawas itu sendiri.

Dalam Pasal 67 ayat (3) UUJNP, Majelis Pengawas Notaris memiliki berbagai unsurunsur yaitu berupa:

1. Terdapat tiga (3) orang dalam pemerintahan;

2. Organisasi Notaris berjumlah terdiri tiga (3);

3. Dan ahli akademisi berjumlah tiga (3).

Mengacu pada UUJNP, dapat dikatakan bahwa pengawasan oleh Notaris terdapat jenjang serta tingkatan-tingkatan yang masing-masing tingkatan itu terdapat kewenangan dan tugas-tugas di dalam pengawasan masing-masing. Pengawasan kepada Notaris pada Kabupaten/Kota dilakukan oleh Majelis Pengawas Daerah sebagaimana yang ditentukan pada Pasal 69 UUJNP.

Pada tingkatan berikutnya, pengawasan dilakukan oleh Majelis Pengawas Wilayah Notaris di Ibukota Propinsi. Masing-masing pada tingkatan itu, tidak hanya dilihat dari tempat kedudukannya tetapi juga dilihat dari pembagian tugasnya serta kewenangannya. Dalam lembaga pengawasan pada tingkat akhir dibentuk dan berkedudukan di Ibukota Negara Kesatuan Republik Indonesia, yakni Daerah Khusus Ibukota (DKI) Jakarta oleh Menteri yaitu Majelis Pengawas Pusat Notaris.

Sebagaimana telah dipaparkan di atas, setiap tingkatan Majelis Pengawas Notaris memiliki perbedaan dalam hal tugas dan kewenangan yang dimilikinya. Ketentuan terkait tugas dan wewenang yang dimiliki oleh Majelis Pengawas Pusat masih tunduk pada ketentuan Undang-Undang Nomor 30 Tahun 2004 tentang Jabatan Notaris. Ketentuan terkait jabatan Notaris tidak seluruhnya diubah oleh Undang-Undang Nomor 2 Tahun 2014 Tentang Perubahan Atas Undang-Undang Nomor 30 Tahun 2004 Tentang Jabatan Notaris, oleh sebab itu terhadap pasal-pasal yang tidak berubah tetap diberlakukan ketentuan yang ada pada Undang-Undang Nomor 30 Tahun 2004 tentang Jabatan Notaris.

Sanksi administratif dapat dijatuhkan kepada Notaris oleh Majelis Pengawas Wilayah dan Majelis Pengawas Pusat sesuai dengan kewenangannya yang diatur dalam UUJN. Apabila terbukti bersalah, Notaris dapat diberikan sanksi peringatan lisan maupun tertulis oleh Majelis Pengawas Wilayah hingga sanksi pemberhentian sementara oleh Majelis Pengawas Pusat. Terhadap sanksi yang dijatuhkan oleh Majelis Pengawas tersebut, Notaris diberikan kesempatan untuk mengajukan keberatan kepada Majelis Pengawas yang menjatuhkan sanksi kepadanya.

Notaris dapat mengajukan keberatan atas putusan sanksi dari Majelis Pengawas baik terhadap sanksi berupa peringatan lisan maupun peringatan tertulis, kepada masingmasing instansi MPW yang mengeluarkan keputusan, dan jika Notaris tersebut masih tidak puas, maka dapat mengajukan banding kepada instansi yang lebih tinggi, yakni diteruskan hingga ke MPP. Hal ini berdasarkan Pasal 33 Peraturan Menteri Hukum 
dan Hak Asasi Manusia Republik Indonesia Nomor: M.02.Pr.08.10 Tahun 2004 Tentang Tata Cara Pengangkatan Anggota, Pemberhentian Anggota, Susunan Organisasi, Tata Kerja, dan Tata Cara Pemeriksaan Majelis Pengawas Notaris, yang mengatur bahwa baik pelapor maupun terlapor yang merasa keberatan atas putusan MPW berhak mengajukan upaya hukum banding kepada MPP.

Dalam kasus Notaris X, MPW Provinsi Bali telah melampaui kewenangannya dalam memutus dan menjatuhkan sanksi. Sanksi berupa pemberhentian sementara yang diberikan kepada Notaris X jelas diluar kewenangan MPW Provinsi Bali yang didasari pada ketentuan Pasal 73 ayat (1) huruf e UUJN. Atas putusan MPW Provinsi Bali tersebut, Notaris X menempuh upaya hukum banding kepada MPP.

Berdasarkan hasil wawancara dengan Notaris $X$, Notaris $X$ menilai bahwa proses pemeriksaan hingga pengambilan keputusan oleh MPP telah dilaksanakan sesuai dengan Pasal 77 UUJNP dan Pasal 33 jo. Pasal 35 Permenkumham Nomor: M.02.Pr.08.10 Tahun 2004. Dalam pelaksanaannya, terdapat beberapa ketentuan yang harus dilaksanakan Notaris $X$ dalam mengajukan upaya hukum banding tersebut. Pertama, upaya hukum banding yang dilaksanakan Notaris $X$ tersebut harus dinyatakan dalam jangka waktu paling lambat 7 (tujuh) hari kalender terhitung sejak putusan dibacakan. Apabila pelapor maupun terlapor tidak hadir pada saat pembacaan putusan, maka pelapor maupun terlapor dapat memberikan pernyataan akan melakukan upaya hukum banding dalam jangka waktu paling lambat 7 (tujuh) hari kalender terhitung sejak putusan tersebut diterima.

Kedua, Notaris $\mathrm{X}$ sebagai Pembanding diwajibkan untuk menyampaikan memori banding. Memori banding oleh Notaris $\mathrm{X}$ tersebut harus disampaikan dalam jangka waktu paling lambat 14 (empat belas) hari kalender terhitung sejak akan adanya upaya hukum banding. Memori banding yang diterima wajib disampaikan kepada terbanding dalam jangka waktu paling lambat 7 (tujuh) hari kalender terhitung sejak diterima oleh Sekretariat MPW Provinsi Bali. Apabila pembanding melewati batas waktu penyampaian memori banding sebagaimana yang telah diatur, maka secara otomatis pernyataan banding tersebut akan diputus tidak dapat diterima oleh Majelis Pengawas Pusat.

Memori banding yang dibuat Notaris $\mathrm{X}$ memuat:

1. Judul beserta nomor putusan MPW Provinsi Bali;

2. Identitas para pihak yang bersengketa;

3. Pernyataan banding yang disertai amar putusan MPW Provinsi Bali;

4. Fakta kejadian;

5. Fakta hukum;

6. Pertimbangan hukum; dan

7. Penutup.

Ketiga, berkas perkara banding tersebut harus disampaikan dalam bentuk hardcopy dan softcopy mulai dari laporan pengaduan masyarakat, berita acara pemeriksaan dan rekomendasi MPD, berita acara pemeriksaan dan putusan MPW, pernyataan banding, serta memori dan kontra memori banding. Proses pemeriksaan perkara tingkat banding oleh Majelis Pemeriksa Pusat baru akan dimulai setelah berkas lengkap diterima oleh Sekretariat MPP dan dicatat dalam register banding. 
Dalam pelaksanaan persidangan oleh MPP yang terbuka untuk umum, untuk memperkuat dan meyakinkan pengambilan keputusan, Majelis Pemeriksa Pusat memanggil Notaris $\mathrm{X}$ ke Jakarta untuk dilakukan pemeriksaan guna didengar keterangannya.

Pada kasus Notaris $X$, memori banding yang diserahkan dianggap cukup beralasan oleh Majelis Pemeriksa Pusat sehingga dalam putusannya, MPP memutuskan untuk membatalkan putusan MPW Provinsi Bali dan membebaskan Notaris X dari segala tuntutan. Proses persidangan hingga turunnya putusan oleh MPP tersebut tidak memakan waktu lebih dari 30 (tiga puluh) hari. Putusan Majelis Pemeriksa Pusat tersebut kemudian wajib diteruskan kepada Menteri dan salinannya diberikan kepada pelapor, terlapor, Majelis Pengawas Daerah, Majelis Pengawas Wilayah Provinsi Bali, dan Pengurus Pusat Ikatan Notaris Indonesia, dalam jangka waktu maksimal 30 (tiga puluh) hari kalender terhitung sejak putusan dibacakan.

\section{Kesimpulan}

Majelis Pengawas Wilayah Provinsi Bali selaku Badan atau Jabatan Tata Usaha Negara (TUN) memiliki kewenangan untuk melakukan suatu perbuatan hukum yakni, mengeluarkan Surat Keputusan atau Ketetapan yang berkaitan dengan hasil yang dilakukan selama dalam pengawasan terhadap Notaris, dan juga pemeriksaan atau penjatuhan sanksi yang ditujukan kepada Notaris. Dalam kedudukannya tersebut, Surat Keputusan atau Ketetapan Majelis Pengawas Wilayah Provinsi Bali dapat dijadikan objek gugatan oleh Notaris maupun pihak lain yang merasa kepentingannya dirugikan ke Pengadilan Tata Usaha Negara (PTUN) sebagai sengketa Tata Usaha Negara. Akan tetapi, hingga tahun 2018 belum pernah ada keputusan Majelis Pengawas Wilayah Provinsi Bali yang digugat hingga ke Peradilan Tata Usaha Negara. Dalam kasus Notaris X, MPW Provinsi Bali telah melampaui kewenangannya dalam memutus dan menjatuhkan sanksi. Sanksi berupa pemberhentian sementara yang diberikan kepada Notaris X jelas diluar kewenangan MPW Provinsi Bali yang didasari pada ketentuan Pasal 73 ayat (1) huruf e UUJN. Atas putusan MPW Provinsi Bali tersebut, Notaris X menempuh upaya hukum banding kepada MPP. Berdasarkan hasil wawancara dengan Notaris $X$, Notaris $X$ menilai bahwa proses pemeriksaan hingga pengambilan keputusan oleh MPP telah dilaksanakan sesuai dengan Pasal 77 UUJN dan Pasal 33 jo. Pasal 35 Permenkumham Nomor: M.02.Pr.08.10 Tahun 2004 yang menghasilkan putusan untuk membatalkan putusan MPW Provinsi Bali dan membebaskan Notaris $X$ dari segala tuntutan.

\section{Daftar Pustaka}

\section{$\underline{\text { Buku }}$}

Adjie, Habib, 2011, Majelis Pengawas Notaris sebagai Pejabat Tata Usaha Negara, Refika Aditama, Bandung.

Camblis William J. dan Robert B. Seidman, 1982Law, Order, and Power, Reading, Mess Addison, Wesly. 
Hadjon, Philipus M. dan Tatiek Sri Djatmiati, 2008, Argumentasi Hukum, Gajah Mada University Press, Yogyakarta.

Indroharto, 1993, Usaha Memahami Undang-Undang Tentang Peradilan Tata Usaha Negara Buku ke-I Beberapa Pengertian Dasar Hukum Tata Usaha Negara, Pustaka Sinar Harapan, Jakarta.

Kohar, A., 2005, Notaris Dalam Praktek Hukum, Alumni, Bandung.

Marbun, S.F., 2001, Menggali dan Menemukan Asas-Asas Umum Pemerintahan yang Baik di Indonesia (Dimensi-Dimensi Pemikiran Hukum Administrasi Negara), UII Press, Yogyakarta.

Rahardjo, Satjipto, 2000, Ilmu Hukum, PT. Citra Aditya Bakti, Bandung.

Soesanto, R., 2007, Tugas, Kewajiban dan Hak-Hak Notaris, Wakil Notaris, Pradnya Paramita, Jakarta.

\section{Jurnal}

Parsa, I Wayan, Kadek Sarna dan Nengah Suharta, 2016, “Implikasi Yuridis Legalitas Kewenangan (Rechtmatigheid) Majelis Kehormatan Dalam Pembinaan Notaris Sebagai Pejabat Publik", Acta Comitas Jurnal Hukum Kenotariatan Volume I Nomor 2 Halaman 131-293, Agustus 2016.

Putra, D. N. R. A., \& Purwani, S. P. M. (2016). Pengawasan Notaris Oleh Majelis Pengawas Notaris Daerah Pasca Putusan MK No. 49/Puu-X/2012. Jurnal Magister Hukum Udayana (Udayana Master Law Journal), 5(4), 783-804. 